\title{
Two-Dimensional Model of Ciliwung River Flood in DKI Jakarta for Development of the Regional Flood Index Map
}

\author{
Adam Formánek ${ }^{1}$, Rasmiaditya Silasari ${ }^{2}$, M. Syahril Badri Kusuma ${ }^{3}$ \& \\ Hadi Kardhana ${ }^{3}$ \\ ${ }^{1}$ Department of Hydraulics and Hydrology, Faculty of Civil Engineering, \\ Czech Technical University in Prague, \\ Thákurova 7, Praha 6-Dejvice, 10, 16629, Czech Republic \\ ${ }^{2}$ Faculty of Civil Engineering, Institut Teknologi Bandung, \\ Jalan Ganesha 10, Bandung 40132, Indonesia \\ ${ }^{3}$ Water Resources Engineering Research Group, Faculty of Civil and Environmental \\ Engineering, Institut Teknologi Bandung, Jalan Ganesha 10, Bandung 40132, Indonesia \\ Email: adam.formanek@fsv.cvut.cz
}

\begin{abstract}
The objective of this study was to present a sophisticated method of developing supporting material for flood control implementation in DKI Jakarta. High flow rates in the Ciliwung River flowing through Jakarta regularly causes extensive flooding in the rainy season. The affected area comprises highly densely populated villages. For developing an efficient early warning system in view of decreasing the vulnerability of the locations a flood index map has to be available. This study analyses the development of a flood risk map of the inundation area based on a two-dimensional modeling using FESWMS. The reference event used for the model was the most recent significant flood in 2007. The resulting solution represents flood characteristics such as inundation area, inundation depth and flow velocity. Model verification was performed by confrontation of the results with survey data. The model solution was overlaid with a street map of Jakarta. Finally, alternatives for flood mitigation measures are discussed.
\end{abstract}

Keywords: 2D modeling; Ciliwung River; FESWMS; flood control; flood index map; Jakarta flood.

\section{$1 \quad$ Introduction}

In the province of DKI Jakarta (Daerah Khusus Ibukota Jakarta, Special Capital Region of Jakarta), the Ciliwung River forms the border of two municipalities (kodya): South Jakarta (Jakarta Selatan) and East Jakarta (Jakarta Timur). Hydraulic structures, Manggarai Gate (Pintu Air Manggarai) and Kota Gate (Pintu Air Kota), divert the river flow to the Western Floodway and to the original lower reach of the Ciliwung River. The case study area encompasses the floodplain along the Ciliwung River for a length of about $35 \mathrm{~km}$ upstream from Manggarai Gate. Inundation occurs because of the Ciliwung River overflowing when it is unable to accommodate flood discharge from upstream.

Received September $21^{\text {st }}, 2011,1^{\text {st }}$ Revision June $11^{\text {th }}, 2013,2^{\text {nd }}$ Revision November $12^{\text {th }}, 2013$, Accepted for publication November $18^{\text {th }}, 2013$.

Copyright $\odot 2013$ Published by ITB Journal Publisher, ISSN: 2337-5779, DOI: 10.5614/j.eng.technol.sci.2013.45.3.7 
Flooding occurs frequently every year in Jakarta during the rainy season, causing huge losses. The intended way to drain the water out of the city was by constructing a floodway in the shape of a horseshoe surrounding Jakarta. Accordingly, the Western Floodway (Banjir Kanal Barat) was constructed and still functions until today. However, construction of the Eastern Floodway (Banjir Kanal Timur) came across financial problems and could not be constructed. As a consequence, there are large urban areas regularly affected by floods.

Information about potential flooding is not available, so that the residents have difficulty in making preparations for floods. Studies on flood index maps need to be conducted in order to provide information about the area and depth of potential inundation in the study case area for the benefit of an early urban flood warning system.

The most recent significant flood event, with the greatest impact, occurred in Jakarta in the rainy season at the beginning of 2007. Parameters of this extreme event served as the basis for the development of a flood index map in this study. The flood discharge estimated in the MT Haryono profile is accordant with the discharge of a 100-year return period, so that the resulting inundation may be interpreted as an event with a 100-year return period.

The flood index map was developed using the two-dimensional Finite-Element Surface-Water Modeling System (FESWMS) to simulate the Ciliwung River flood. It is an extension of previous model-based flood index maps that use onedimensional models only [1]. The results obtained from the 2D model are supposed to be closer to the ground state and therefore more accurate.

The model inputs were discharge and water level data obtained from automatic water level recording stations along the Ciliwung River.

Based on the modeling results, the inundation was mapped onto detailed topographic maps. The index map was verified using the data of the inundation area and depths from a survey. In the future, sets of models may be used to predict potential flooding in real-time conditions in view of an early warning system for the Ciliwung River floodplain in Jakarta.

With the results of this study, the early-warning capacity may be increased so that citizens can be more vigilant and reduce the risk of loss. Avoiding substantial losses due to flooding is very beneficial to Jakarta as the capital of Indonesia, with a huge population and a large variety of important activities. 


\section{$2 \quad$ Model Components and Principles}

For the purposes of this study, the U.S. Federal Highway Administration's Finite Element Surface Water Modeling System (FESWMS) was used. The depth-averaged Flo2DH (Flow and Sediment Transport Model), a component of FESWMS, is a computer program that simulates the movement of water and non-cohesive sediment in rivers, floodplains, estuaries, and coastal waters. Flo2DH applies the finite element method to solve steady or unsteady flow equations that describe the two-dimensional depth-averaged surface water flow. Flo2DH can be used when vertical velocities are assumed to be negligible compared to lateral flow [2].

\subsection{Governing Equations}

Equations describing the flow of water in floodplains, estuaries, and other surface water bodies are based on the classical concept of conservation of mass and momentum. Equations describing depth-averaged surface-water flow are found by integrating the three-dimensional mass and momentum transport equations with respect to the vertical coordinate from the bed to the water surface, considering vertical velocities and accelerations to be negligible. The vertically-integrated mass transport equation or continuity equation is:

$$
\frac{\partial H}{\partial t}+\frac{\partial q_{1}}{\partial x}+\frac{\partial q_{2}}{\partial y}=q_{m}
$$

where $q_{1}=U H=$ unit flow rate in the $\mathrm{x}$ direction, $q_{2}=V H=$ unit flow rate in the $y$ direction, $q_{m}=$ mass inflow or outflow rate per unit area, $H=$ water depth, $U$, $V=$ depth-averaged velocity components in the horizontal $x$ and $y$ coordinate directions, respectively and water mass density $\rho$ is considered constant throughout the modeled region. Equations describing momentum transport in the $x$ and $y$ directions, respectively, are as follows:

$$
\begin{aligned}
& \frac{\partial q_{1}}{\partial t}+\frac{\partial}{\partial x}\left(\beta \frac{q_{1}^{2}}{H}+\frac{1}{2} g H^{2}\right)+\frac{\partial}{\partial y}\left(\beta \frac{q_{1} q_{2}}{H}\right)+g H \frac{\partial z_{b}}{\partial x}+\ldots \\
& \ldots \frac{H}{\rho} \frac{\partial p_{a}}{\partial x}-\Omega q_{2}+\frac{1}{\rho}\left[\tau_{b x}-\tau_{s x}-\frac{\partial\left(H \tau_{x x}\right)}{\partial x}-\frac{\partial\left(H \tau_{x y}\right)}{\partial y}\right]=0 \\
& \frac{\partial q_{2}}{\partial t}+\frac{\partial}{\partial x}\left(\beta \frac{q_{1} q_{2}}{H}\right)+\frac{\partial}{\partial y}\left(\beta \frac{q_{1}^{2}}{H}+\frac{1}{2} g H^{2}\right)+g H \frac{\partial z_{b}}{\partial y}+\ldots \\
& \ldots \frac{H}{\rho} \frac{\partial p_{a}}{\partial y}-\Omega q_{1}+\frac{1}{\rho}\left[\tau_{b y}-\tau_{s y}-\frac{\partial\left(H \tau_{y x}\right)}{\partial x}-\frac{\partial\left(H \tau_{y y}\right)}{\partial y}\right]=0
\end{aligned}
$$


where $\beta=$ isotropic momentum flux correction coefficient that accounts for the variation of velocity in the vertical direction, $g=$ gravitational acceleration, $z_{b}=$ channel bottom elevation, $\rho=$ water mass density, $p_{a}=$ atmospheric pressure at the water surface, $\Omega=$ Coriolis parameter, $\tau_{b x}$ and $\tau_{b y}=$ bed shear stresses acting in the $x$ and $y$ directions, respectively, $\tau_{s x}$ and $\tau_{s y}=$ surface shear stresses acting in the $x$ and $y$ directions, respectively, and $\tau_{x x}, \tau_{x y}, \tau_{y x}$, and $\tau_{y y}=$ shear stresses caused by turbulence where, for example, $\tau_{x y}$ is the shear stress acting in the $x$ direction on a plane that is perpendicular to the y direction [2].

\section{$2.2 \quad$ Geometry}

The finite element mesh was generated using the SMS (Surface-Water Modeling System) software. SMS is a pre- and post-processor for surface water modeling and analysis. It includes two-dimensional finite element, twodimensional finite difference, three-dimensional finite element and onedimensional step-backwater modeling tools. The modules of SMS comprise interfaces specifically designed to facilitate the utilization of several numerical models [2].

The domain was determined on the basis of the topographic map of DKI Jakarta developed by Department of Public Works (Dinas Pekerjaan Umum). It comprises the lower area of the Ciliwung River basin in the section upstream from Manggarai Gate to the border of DKI Jakarta and Depok. The length of the included river section is $35 \mathrm{~km}$. There are two affected municipalities with eight districts (kecamatan) and 21 villages (kelurahan) within this domain.

Considering the length of the modeled river section, the domain was divided into four overlapping parts (Table 1) to make the solution less demanding on the hardware.

Table 1 Lengths of model sections.

\begin{tabular}{cc}
\hline Section of Model & $\begin{array}{c}\text { Length of River Reach } \\
(\mathbf{k m})\end{array}$ \\
\hline Manggarai Gate-Cawang & 8.12 \\
Cawang-Balekambang & 9.40 \\
Balekambang-Tanjung Barat & 6.80 \\
Tanjung Barat-DKI Jakarta border & 11.38 \\
\hline
\end{tabular}

The structure of the finite element mesh followed the topography within the domain. The mesh was created by conversion of the contour lines from the topographic map imported into SMS and manual adjustment. The result was a finite element mesh consisting of triangular and quadrilateral elements. The average density of the mesh was about 6,000 elements per $1 \mathrm{~km}^{2}$. The area of 
element depends on the terrain slope with efforts to retain only a small difference in the terrain elevation within one element, most importantly to achieve accurate results. Therefore, the shape of most elements in the mesh is more or less elongated, whereby the elongation follows the direction of the contour lines. Topographic data with a vertical resolution of 1 meter were brought from the topographic map and a more precise geometry of the river channel was derived from a detailed Ciliwung River profile [3].

\subsection{Case Study Area}

The case study area comprises an extremely densely populated and flood-prone location in DKI Jakarta, where vulnerability is significant due to high poverty. The average population density in DKI Jakarta is about 14,500 inhabitants per $\mathrm{km}^{2}[4,5]$. The main object of analysis was a section of the Ciliwung River (from Manggarai Gate to Depok) and its inundation area. The domain includes 21 more or less flood-prone villages.

\subsection{Steady State Solution}

The final solution of the 2D modeling was further transformed into an inundation map that represents conditions within the affected area at the time of peak discharge. Therefore a steady state analysis, based on the peak discharge values, was performed. A steady state analysis does not display flood propagation over time; on the other hand, it does provide sufficiently precise information about the extreme situation on which the flood index map is based.

\subsection{Procedure of Successive Computation}

Since the domain was divided into four segments, representing four Ciliwung River sections, the process of computation comprised four steps. First, the most downstream section was computed, followed by computation of the second section using the achieved results. The same process was repeated for the remaining sections.

Each segment of the model overlapped the previous and the next segment for an average length of 200 meters. Correct connection of the model sections was controlled within the overlapping segments.

\subsection{Model Input Data}

\subsubsection{Boundary Conditions}

For each model section, setting both the inflow and outflow boundary conditions was required. Considering subcritical flow within all domains, the 
inflow boundary condition is a value of discharge or average velocity in the inflow profile, while the outflow boundary condition is a value of depth or water surface elevation in the outflow profile. There are one outflow profile and two inflow profiles (main channel of Ciliwung River and tributary) in each model section.

The resulting water surface or depth values in the inflow profile of the downstream model section were used as the downstream boundary condition for the corresponding profile of the next section. For example, the model of the first section (Manggarai Gate-Cawang) provided the set of water surface and water depth data within the first domain. The resulting values of water surface in the profile, which was defined as the Ciliwung River cross section at Cawang, was then applied as the downstream boundary condition for the same cross section in the second model section (Cawang-Balekambang). This approach was possible for all following model sections because the each section overlapped the previous one.

Table 22007 flood data recorded by AWLR stations.

\begin{tabular}{ccccc}
\hline AWLR Station & $\begin{array}{c}\text { River Station } \\
{[\mathbf{k m}]}\end{array}$ & $\begin{array}{c}\text { Peak Discharge } \\
\mathbf{2 0 0 7}\left[\mathbf{m}^{3} / \mathbf{s}\right]\end{array}$ & $\begin{array}{c}\text { Water } \\
\text { level }[\mathbf{m}]\end{array}$ & $\begin{array}{c}\text { Date, Time of } \\
\text { Flood Peak }\end{array}$ \\
\hline p.a. Manggarai & 0.000 & & 10.90 & $4.2 .2007,6: 00$ \\
MT Haryono & 7.614 & & & $4.2 .2007,4: 00$ \\
Sugu Tamu & 41.177 & & 4.92 & $3.2 .2007,18: 00$ \\
Jembatan Panus & 46.980 & 373.4 & & 3.2 .2007 \\
Ratu Jaya & 49.843 & & & \\
Kampung & & & & \\
Kelapa & 57.607 & & & \\
\hline
\end{tabular}

The discharge and water surface elevation (or water depth) input data were obtained from AWLR stations (Table 2). The data were provided by Balai Besar Wilayah Sungai Ciliwung-Cisadane. Unfortunately most of the measurement facilities were affected by the devastating effects of the extreme flood, so that only few usable data are available.

Table 3 River station of AWLR stations and inflow profiles of model sections.

\begin{tabular}{ccc}
\hline AWLR Station & Inflow Profile & River Station $[\mathbf{k m}]$ \\
\hline p.a. Manggarai & & 0.000 \\
MT Haryono & & 7.614 \\
& Cawang & 8.121 \\
& Balekambang & 17.009 \\
& Tanjung Barat & 23.813 \\
Sugu Tamu & DKI Jakarta boarder & 35.192 \\
\hline
\end{tabular}


The water surface measurement from p.a. Manggarai Station was used as the initial input for the water surface elevation representing the outflow boundary condition in the first model section. Evaluation of the discharge values for the inflow boundary conditions required additional calculations since the inflow profiles did not correspond with the AWLR station locations (Table 3).

Reliable records of the water level at p.a. Manggarai Station and almost complete records from the MT Haryono Station from the 2007 flood event were available. At MT Haryono recording was interrupted for a couple of hours before the flood peaked - on 4.2.2007 at 2:00 am, while the peak is estimated to have been at 4:00 am. Furthermore, a rating curve for the MT Haryono profile was available [3].

For the purpose of peak discharge estimation in the MT Haryono profile, a correlation between the p.a. Manggarai and MT Haryono station data was applied. Optimal correlation was realized for the water level data set from p.a. Manggarai Station and the data set from MT Haryono Station, with a two-hour difference. This corresponds with the speed of the flood propagation - two hours on a $7.6 \mathrm{~km}$ long river section equals an average velocity of flow of 1.05 $\mathrm{m} / \mathrm{s}$.

Afterwards, the water level data from the MT Haryono profile were extrapolated based on this correlation until the estimated time of flood peak (Figure 1). The last recorded value from MT Haryono Station was $8.52 \mathrm{~m}$ (at 2:00 am). The extrapolated line culminated in a value of $8.97 \mathrm{~m}$ (at 4:00 am).

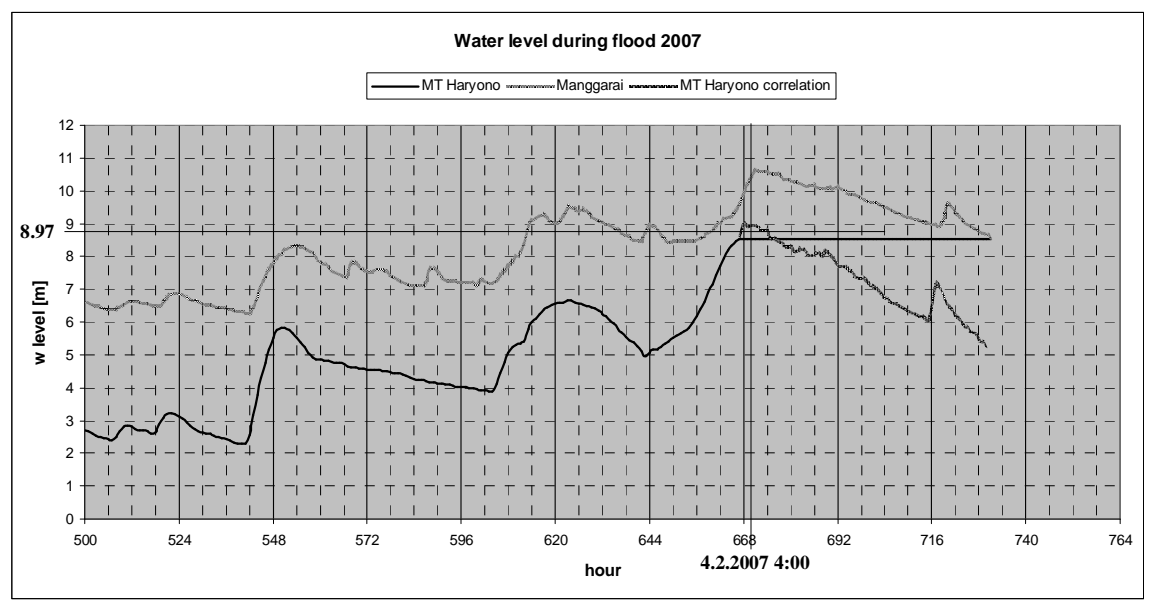

Figure 1 Water level data correlation, extrapolation of MT Haryono data, peak water level estimation. 
The culmination point was then transferred into the MT Haryono rating curve (Figure 2) in view of obtaining the value of peak discharge $\left(531.5 \mathrm{~m}^{3} / \mathrm{s}\right)$.

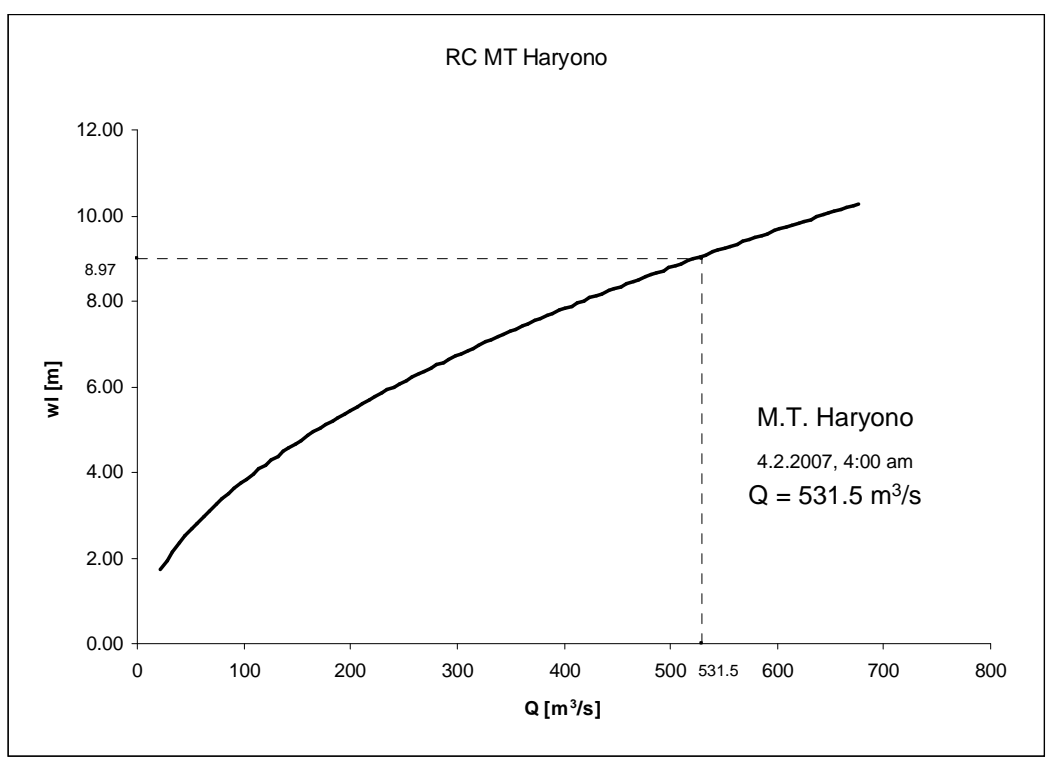

Figure 2 Rating curve of MT Haryono profile, peak discharge estimation.


Figure 3 Discharge values allocation, based on sub-basin areas.

Consequently, two applicable peak discharge values were available: $531.5 \mathrm{~m} / \mathrm{s}$ from the MT Haryono profile and $373.4 \mathrm{~m}^{3} / \mathrm{s}$ from the Ratu Jaya profile. These 
values were used for discharge (inflow boundary condition) determination for every particular section of the model. Discharge value allocation in the four inflow profiles, between MT Haryono and Ratu Jaya, was based on a computation of the Ciliwung River sub-basin area. The sub-basin areas are presented in Figure 3.

Table 4 Discharge difference division between MT Haryono and Ratu Jaya station.

\begin{tabular}{|c|c|c|c|}
\hline River Section & $\begin{array}{c}\text { Sub-Basin } \\
\text { Area }\left[\mathbf{k m}^{2}\right]\end{array}$ & $\begin{array}{c}\text { Sub-Basin } \\
\text { Area [\%] }\end{array}$ & $\begin{array}{c}\text { Disch. Diff. } \\
{\left[\mathrm{m}^{3} / \mathrm{s}\right] * *}\end{array}$ \\
\hline Cawang-Balekambang * & 10.16 & 12.3 & 19.4 \\
\hline Balekambang-Tanjung Barat* & 6.16 & 7.4 & 11.7 \\
\hline $\begin{array}{l}\text { Tanjung Barat-DKI Jakarta } \\
\text { border * }\end{array}$ & 15.61 & 18.8 & 29.8 \\
\hline DKI Jakarta border-Sugu Tamu & 9.06 & 10.9 & 17.3 \\
\hline Sugu Tamu-Jembatan Panus & 17.92 & 21.6 & 34.2 \\
\hline Jembatan Panus-Ratu Jaya & 24.01 & 29.0 & 45.8 \\
\hline Total & 82.92 & 100.0 & 158.1 \\
\hline
\end{tabular}

The difference in discharge between Ratu Jaya and MT Haryono was 158.1 $\mathrm{m}^{3} / \mathrm{s}$. This value was divided over six sections between the stations according to the percentage of the sub-basin area of each section (Table 4). For the model requirements only three values in the inflow profiles were applied.

$$
\begin{aligned}
Q_{i} & =p_{i}\left(Q_{M T H}-Q_{R J}\right)=p_{i} \cdot 158.1 \\
p_{i} & =\frac{A i}{A}
\end{aligned}
$$

where $Q_{i}=$ discharge difference between two profiles, $p_{i}=$ percentage of subbasin area from the sum of sub-basin areas between the MT Haryono and Ratu Jaya station, $Q_{M T H}=$ peak discharge in MT Haryono profile, $Q_{R J}=$ peak discharge in Ratu Jaya profile, $A_{i}=$ sub-basin area, $A=$ sum of sub-basin areas between MT Haryono and Ratu Jaya station.

Table 5 Discharge values in inflow profiles (inflow boundary conditions).

\begin{tabular}{lcc}
\hline \multicolumn{1}{c}{ Section of Model } & \multicolumn{2}{c}{ Inflow Boundary Condition [m $\mathbf{3} / \mathbf{s}]$} \\
\cline { 2 - 3 } & Main Channel & Tributary \\
\hline Manggarai Gate-Cawang & 531.5 & 19.0 \\
Cawang-Balekambang & 512.1 & 19.4 \\
Balekambang-Tanjung Barat & 500.4 & 11.7 \\
Tanjung Barat-DKI Jakarta boarder & 470.6 & 29.8 \\
\hline
\end{tabular}


Finally, the total discharge values for the inflow profiles (Table 5) were set as the sum of the discharges in the Ratu Jaya profile and the discharges from the sub-basin of all upstream sections. Furthermore, the sub-basin discharge value in every model section was introduced as tributary inflow. Hence, the discharge from the sub-basin was concentrated in one profile: the junction of tributary and main channel. This simplification was applied considering that the tributary inflow was much smaller than the discharge in the main channel. The only unknown value was the discharge from sub-basin no. 1 (Manggarai GateCawang), because the discharge in the Manggarai Gate profile was unknown. This value was estimated in the same way as the previous values, from the subbasin area, where the rate of contribution from the sub-basin was assumed equal to that between the Ratu Jaya and the MT Haryono profile.

$$
Q_{1}=\frac{A_{1}}{A}\left(Q_{M T H}-Q_{R J}\right)=\frac{A_{1}}{A} \cdot 158.1
$$

where $Q_{1}=$ discharge difference between MT Haryono and p.a. Manggarai profiles, $A_{1}=$ area of sub-basin no. 1 .

Setting the outflow boundary conditions started from the downstream profile of the first model section, i.e. the p.a. Manggarai profile. Recorded data were available with a water level peak of $10.90 \mathrm{~m}$.

After the first model run, the resulting water level in the next downstream profile (Cawang) was applied to the second model section. The same process was repeated until the last model section. The resulting values of outflow boundary conditions were presented in Table 6 .

Table 6 Water surface elevation values in outflow profiles (outflow boundary conditions).

\begin{tabular}{lc}
\hline \multicolumn{1}{c}{ Section of Model } & Outflow Boundary Condition [m] \\
\hline Manggarai Gate - Cawang & 10.90 \\
Cawang - Balekambang & 18.48 \\
Balekambang - Tanjung Barat & 24.07 \\
Tanjung Barat - DKI Jakarta boarder & 29.08 \\
\hline
\end{tabular}

\subsubsection{Roughness Parameters}

Roughness parameters of the modeled inundation area were represented by Manning's roughness coefficient $n$. In view of model simplification, only two types of surface roughness were applied: roughness of river channel and roughness of inundation. This simplification was made considering the large domain with practically continual conditions; the river characteristics are 
similar along the model section and the inundation area consists of a compact, densely populated region.

Manning's roughness coefficient of the river channel was estimated at $n=$ 0.034 , which corresponds with a natural winding stream with some pools and shoals. This value was calculated on the basis of the rating curve in the MT Haryono profile [1]. For inundation, the interval of Manning's roughness coefficient was estimated at $n=0.08-0.20$ (area with very dense housing) based on the field survey. A calibration was performed for more precise value acquirement.

The solution was performed taking the parameters of the 2007 flood into consideration, including its large inundation area. The precision of all available topography and hydrology data was quite low. Therefore a more detailed estimation of roughness, especially in the highly densely populated area, was irrelevant.

\section{$3 \quad$ Model Verification}

The most indistinct model parameter was the inundation roughness. This parameter covered most of the domain area. Moreover, a significant difference in result was not achieved by alternation of the channel roughness parameter. Therefore, a calibration was performed on the basis of a single inundation roughness parameter alternation.

Reference data for the calibration were collected from the survey in the 2007 inundation area along the Ciliwung River. The data set contained geographical position of survey points, elevation of terrain and depth of inundation during the 2007 flood. The survey data were acquired in situ by collecting information from local people and recording visible traces left by the flood. The scope of the field survey was limited by time and financial constraints.

Twelve points from the survey with the most reliable and accurate values were chosen and applied in the calibration process. Taking into consideration the size of the domain, these twelve points were not enough; in this study they were only used to represent the system of the calibration process. For a more accurate solution a more detailed survey needs to be conducted.

Subsequently, a first model run was performed. The results were saved, the parameter of inundation roughness was replaced and the next run was performed. After a series of model runs, the results were compared with the reference data (Table 7). 
Table 7 Water depth during 2007 flood, survey data, model results.

\begin{tabular}{|c|c|c|c|c|c|c|c|c|c|c|c|}
\hline \multirow{3}{*}{ Point Location } & \multicolumn{11}{|c|}{ Water Depth [m] } \\
\hline & \multirow{2}{*}{ Survey } & \multicolumn{10}{|c|}{ Model Results * } \\
\hline & & \multicolumn{2}{|c|}{$n=0.08$} & \multicolumn{2}{|c|}{$n=0.10$} & \multicolumn{2}{|c|}{$n=0.12$} & \multicolumn{2}{|c|}{$n=0.15$} & \multicolumn{2}{|c|}{$n=0.20$} \\
\hline J1. Kebon Baru, Kebon Baru & 4.0 & 3.4 & -0.6 & 3.8 & -0.2 & 4.1 & 0.1 & 4.5 & 0.5 & 5.1 & 1.1 \\
\hline J1. Kebon Baru, Kebon Baru & 4.0 & 3.3 & -0.7 & 3.7 & -0.3 & 4.0 & 0.0 & 4.4 & 0.4 & 4.9 & 0.9 \\
\hline Pengadegan & 3.0 & 2.4 & -0.6 & 2.8 & -0.2 & 3.2 & 0.2 & 3.6 & 0.6 & 4.3 & 1.3 \\
\hline Pengadegan & 2.0 & 1.7 & -0.3 & 2.1 & 0.1 & 2.5 & 0.5 & 3.0 & 1.0 & 3.6 & 1.6 \\
\hline Pengadegan & 3.3 & 2.8 & -0.5 & 3.1 & -0.2 & 3.4 & 0.1 & 3.9 & 0.6 & 4.5 & 1.2 \\
\hline $\begin{array}{l}\text { J1. Pengadegan Timur } 1 \text {, } \\
\text { Pengadegan }\end{array}$ & 1.9 & 1.5 & -0.4 & 1.8 & -0.1 & 2.1 & 0.2 & 2.6 & 0.7 & 3.2 & 1.3 \\
\hline $\begin{array}{l}\text { J1. Pengadegan Timur } 3 \text {, } \\
\text { Pengadegan } \\
\text { J1. Angsana Raya, Pejaten }\end{array}$ & 1.6 & 1.1 & -0.5 & 1.4 & -0.2 & 1.7 & 0.1 & 2.1 & 0.5 & 2.8 & 1.2 \\
\hline Timur & 0.0 & 0.0 & 0.0 & 0.1 & 0.1 & 0.5 & 0.5 & 1.1 & 1.1 & 1.9 & 1.9 \\
\hline J1. Kemuning, Pejaten Timur & 1.8 & 1.6 & -0.2 & 2.0 & 0.2 & 2.4 & 0.6 & 2.9 & 1.1 & 3.7 & 1.9 \\
\hline Pejaten Timur & 0.1 & 0.0 & -0.1 & 0.0 & -0.1 & 0.0 & -0.1 & 0.6 & 0.5 & 1.4 & 1.3 \\
\hline Pejaten Timur & 0.0 & 0.0 & 0.0 & 0.0 & 0.0 & 0.5 & 0.5 & 1.1 & 1.1 & 1.8 & 1.8 \\
\hline J1. Jembatan 1, Balekambang & 1.8 & 1.2 & -0.6 & 1.6 & -0.2 & 2.0 & 0.2 & 2.6 & 0.8 & 3.3 & 1.5 \\
\hline STANDARD DEVIATION & & \multicolumn{2}{|c|}{0.24} & \multicolumn{2}{|c|}{0.15} & \multicolumn{2}{|c|}{0.22} & \multicolumn{2}{|c|}{0.26} & \multicolumn{2}{|c|}{0.33} \\
\hline
\end{tabular}

Comparison of the model results with the reference data shows the best match for Manning's roughness coefficient at $n=0.10$ (with lowest standard deviation equal to $0.15 \mathrm{~m}$ ). This value was then used for all inundation area within the domain. For a more precise solution, variation of Manning's roughness coefficient $\mathrm{n}$ should be considered.

\section{$4 \quad$ Results and Discussion}

2D inundation modeling of a Ciliwung River section in DKI Jakarta was performed in order to develop a flood index map. This map may serve as an information source about potential flooding and is based on the 2007 flood event.

The steady state solution of the 2D model provided the following results:

1. 2007 flood inundation area

2. depth of inundation within the domain

3. velocity of flow within inundation

The flood inundation area for every village affected by the extreme flood event of 2007 is presented in Table 8. [6]

The results from the FESWMS model were converted to a CAD file and connected with a street map of Jakarta, resulting in a digital inundation map. The map consists of two parts: a map of inundation depths and a map of 
velocities (samples are presented in Figures 5 and 6). The depth resolution is 1 $\mathrm{m}$, corresponding to the topographic map of DKI Jakarta, and the velocity resolution is $0.5 \mathrm{~m} / \mathrm{s}$.

Table 8 Ciliwung River inundation area in DKI Jakarta.

\begin{tabular}{lrrr}
\hline \multicolumn{1}{c}{ Village (Kelurahan) } & $\begin{array}{c}\text { Village area } \\
{\left[\mathbf{m}^{\mathbf{2}}\right]}\end{array}$ & $\begin{array}{c}\text { Inundation } \\
\text { area }\left[\mathbf{m}^{\mathbf{2}]}\right.\end{array}$ & $\begin{array}{c}\text { Inundation } \\
\text { area [\%] }\end{array}$ \\
\hline Manggarai * & $1,068,142$ & 329,435 & 30.8 \\
Bukit Duri * & $1,074,590$ & 457,295 & 42.6 \\
Kebon Baru * & $1,257,786$ & 402,514 & 32.0 \\
Cikoko & 666,426 & 82,059 & 12.3 \\
Pengadegan & 986,266 & 167,713 & 17.0 \\
Rawajati & $1,533,213$ & 187,165 & 12.2 \\
Pejaten Timur & $2,973,569$ & 398,041 & 13.4 \\
Tanjung Barat & $3,580,042$ & 307,805 & 8.6 \\
Lenteng Agung & $3,157,838$ & 220,616 & 7.0 \\
Srengsengsawah & $5,568,097$ & 75,076 & 1.3 \\
Kebon Manggis & 779,650 & 589,178 & 75.6 \\
Kampung Melayu & 479,468 & 391,951 & 81.7 \\
Balimester & 672,067 & 239,621 & 35.7 \\
Bidara Cina & $1,243,502$ & 494,747 & 39.8 \\
Cawang & $1,944,230$ & 395,591 & 20.3 \\
Cililitan * & $1,818,292$ & 346,517 & 19.1 \\
Balekambang & $1,691,469$ & 387,015 & 22.9 \\
Gedong & $2,571,497$ & 182,473 & 7.1 \\
Cijantung & $2,468,211$ & 58,922 & 2.4 \\
Baru & $1,968,301$ & 173,332 & 8.8 \\
Kalisari & $2,522,823$ & 29,318 & 1.2 \\
\hline * Inundation of marked villages was also caused by another stream except the \\
Ciliwung River, which is not included in the inundation area shown in this table.
\end{tabular}

For a comparison of $1 \mathrm{D}$ and $2 \mathrm{D}$ approaches we used a previous study on modeling flood index maps, which only used one-dimensional (1D) models [1]. The advantages of a 1D model are faster processing of geometry data, faster model building and a significantly shorter computation time compared to a 2D solution [7]. For long channels with a narrow inundation area it is suitable to use 1D modeling. The problem comes with large inundation areas, especially in urban areas like Central Jakarta, where it is impossible to represent flow parameters (depth, velocity, direction of flow) realistically with a 1D approach. Especially for the development of flood index maps for large flooded urban areas it is more appropriate to use $2 \mathrm{D}$ modeling, which can realistically simulate real conditions.

The map represents inundation depths and velocities under the conditions of the 2007 flood event in the Ciliwung River basin in the area of DKI Jakarta (Figure 4). 
The solution was performed for steady state conditions, so information about flood propagation is not included. The map represents characteristics during the peak discharge along all river sections. The flood characteristics at each location from the domain were therefore modeled as extreme, i.e. the peak of the 2007 flood.

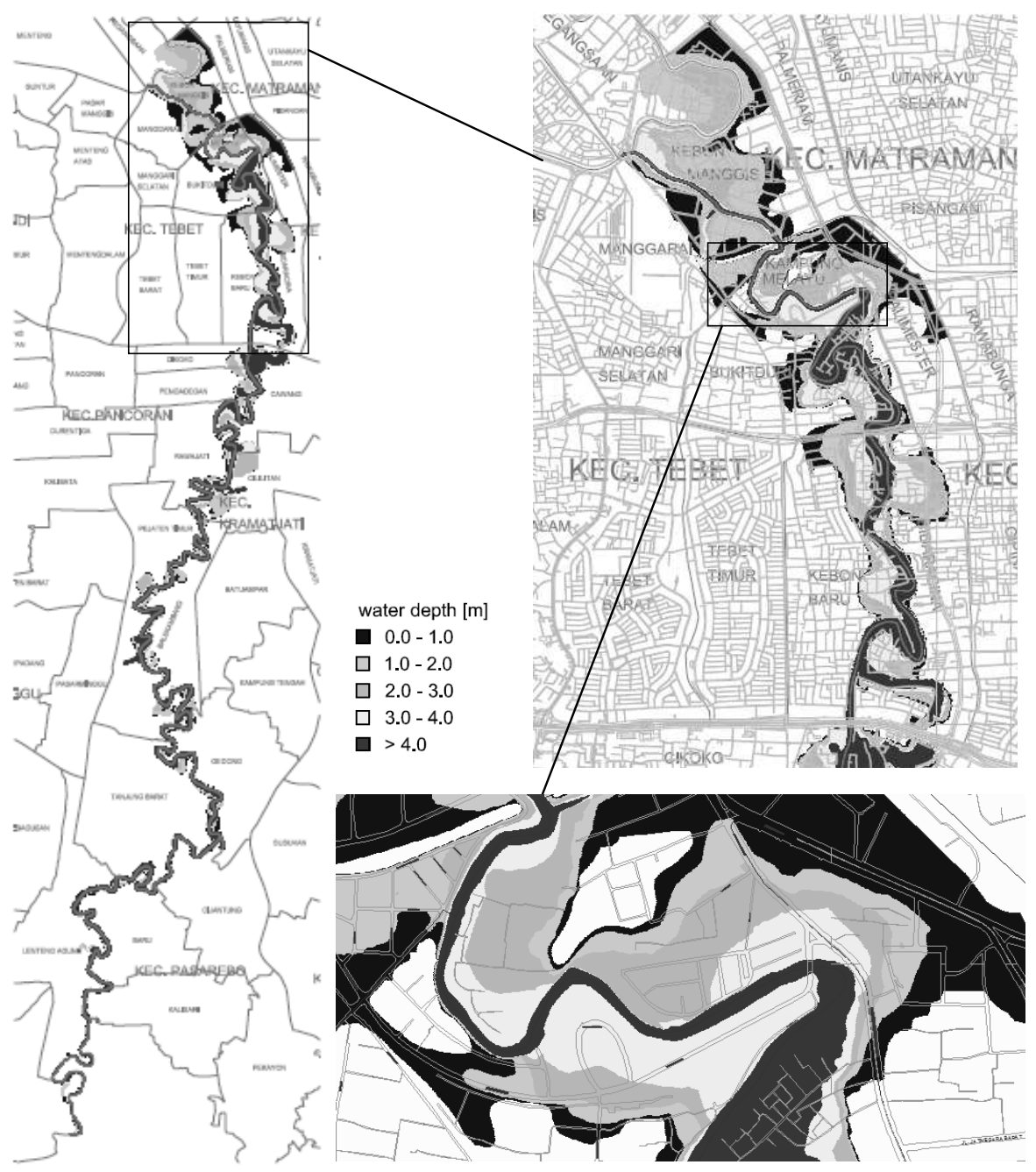

Figure 4 Map of 2007 flood inundation depth, Ciliwung River, DKI Jakarta.

The resulting solution displays the flood-prone areas along the Ciliwung River. The villages most affected, with more than $20 \%$ of flooded area, are Manggarai, 
Bukit Duri, Kebon Baru, Kebon Manggis, Kampung Melayu, Balimester, Bidara Cina, Cawang and Balekambang (Figure 5).

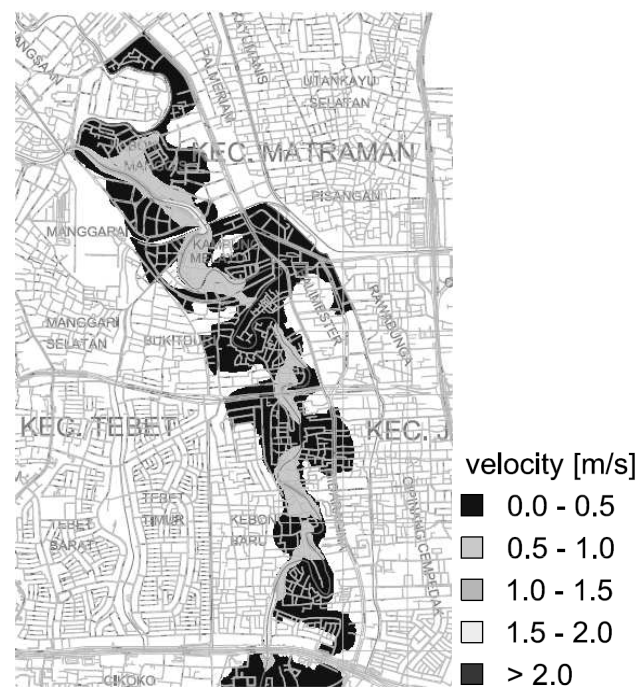

Figure 5 Map of flow velocity within inundated area, section p.a. ManggaraiCawang.

The accuracy of the model results was verified by comparing the results with the survey data. Based on the model calibration, the solution has the best accordance with the survey data when the simplified inundation area roughness parameter is set to Manning's roughness coefficient $n=0.10$.

\section{$5 \quad$ Proposed Measures for Flood Mitigation}

\subsection{Diversion Canal}

One of the measures for flood mitigation seriously discussed for the case study area is the construction of a diversion canal, diverting a portion of the discharge from the Ciliwung River to the Cipinang River in the east and to the Eastern Floodway [8]. The best position for connecting the diversion canal with the Ciliwung River seems to be in the area of South Bidara Cina village. The reason is the proximity of the Ciliwung and the Cipinang river in this area and the possibility to reduce negative impact in the most flood prone villages located downstream (North Bidara Cina and Kebon Baru, Bukit Duri, Manggarai, Kampung Melayu and Kebon Manggis). Other strongly affected villages (Cawang, Balekambang and other villages located upstream) would not be 
protected. Nevertheless, conditions for many people living in a large area would be improved by this measure. More specific locations within the diversion structure and trace of the canal have to be considered with regard to possibilities of land occupation.

The mitigation rate achieved by this measure depends on the size of the discharge portion diverted from the Ciliwung River channel. This study briefly analyses a situation where $50 \%$ of the discharge is diverted.

Inundation was computed using the model described above, reducing the discharge in the Ciliwung River to $265.8 \mathrm{~m} 3 / \mathrm{s}$ (50\% of the 2007 flood discharge). A solution was made for the section from Cawang to p.a. Manggarai with a theoretical location of diversion downstream from the MT Haryono profile. The solution shows conditions during flood in the area downstream from the diversion.

From the results it is clear that a discharge diversion causes significant inundation depth reduction. But the inundation area remains large and many houses are still far from serious protection.

Regarding the model results it should be noted that a flood problem solution using a diversion canal reduces the flood impact in a large area, however, even if the largest part of the flood discharge (50\%) can be diverted, the effect is still not satisfactory. This solution has a number of crucial disadvantages:

1. The need to build large-scale constructions, which will be rarely utilized and need to be maintained.

2. Land occupation on a large scale.

3. The solution only moves the problem from one place to another.

4. The capacity of the Eastern Floodway, available for other joint rivers, is decreased strongly.

It is recommended to consider other flood mitigation measures, replacing, or combined with, the proposed diversion canal.

\subsection{Increasing Capacity of Ciliwung River Channel}

Currently, the Ciliwung River channel is in poor condition. Channel capacity, too low in itself, is strongly decreased by sedimentation, vegetation and objects discarded by people-illegal housing and constructions, trash, etc. Therefore, its capacity is exceeded almost every rainy season. 
The only way to solve the inundation problem is to change the river conditions. This can be done by a structural change of some channel parameters.

Theoretically it is possible to change: 1) river bed slope, 2) channel width, 3) channel depth. Currently, the average width of the Ciliwung River channel in the most flood-prone area is around $30 \mathrm{~m}$. The average slope is 0.0006 and channel depth varies from $3 \mathrm{~m}$ to $8 \mathrm{~m}$.

Due to the location of this river section, in a flat downstream area, a significant change of the river bed slope is not possible. Therefore, increasing the capacity can only be done through appropriate amendments to the width and depth of the channel.

This study shows a brief design of these two channel parameters (in case of a rectangular cross section), based on Manning's formula.

$$
Q=\frac{1}{n} S R^{2 / 3} i^{1 / 2}
$$

where $Q=$ discharge, $n=$ Manning's roughness coefficient, $S=$ cross section area, $R=$ hydraulic radius, $i=$ slope of energy ( $\approx$ river bed slope).

Since the possibility of increasing the depth of the Ciliwung River channel is very limited (the depth can only be increased by constructing levees), it is evident that the channel has to be widened on the long sections. A combination of widening and levee construction should be considered, bearing in mind the local conditions, particularly land availability. The demands on land, together with the anticipated high cost of construction, are the major disadvantages of this solution. Furthermore, the drainage system of the adjacent area, and pumping stations should eventually be an integral part of the design.

The advantage of this solution is that the design can be implemented stepwise, prioritizing the most affected areas. Together with appropriate operation and maintenance, it could provide effective and long-term flood protection.

\section{Conclusions}

In this study, the 2D Finite-Element Surface-Water Modeling System (FEMWS) was applied to simulate extreme flood events in order to develop a flood index map of the area along a section of the Ciliwung River in DKI Jakarta. The $35 \mathrm{~km}$ long section is located between Central Jakarta (with the p.a. Manggarai outflow profile) and the border between DKI Jakarta and Depok. In this section, the Ciliwung River, flowing from south to north, forms the border 
of South Jakarta in the west and East Jakarta in the east. The area around the Ciliwung River is densely populated and its vulnerability is increased by high poverty.

The first step in the development of an early warning system for the protection of the threatened inhabitants is to define the affected area and to predict the flood characteristics within this area with sufficient accuracy. Considerable efforts were spent on developing the flood index map for this purpose. This map can serve as a basic source of information about the potential flood area, depth of inundation and flow velocities.

This study concerns the development of a flood index map based on the application of a 2-dimensional hydraulic model. The U.S. Federal Highway Administration's FESWMS was used, whereby the parameters of the flood event that occurred in the beginning of 2007 served as basic input data.

The steady state solution using the 2007 flood peak discharge was performed, whereby the value of peak discharge was determined by evaluation of recorded data (AWLR stations). Essential records of water levels were acquired from the p.a. Manggarai AWLR station. The peak water level recorded at this station was the initial input for computation of the water level, as well as inundation depth during the 2007 flood event.

The accuracy of the solution was verified by comparing the resulting inundation depth with survey data. From the comparison, sufficient accordance was evident.

The data obtained from the FESWMS model were converted to a digital map and overlaid by a street map of Jakarta, providing information about the flooded area, depth of inundation and flow velocities for the case of a flood with the same parameters as the 2007 event. The depth resolution is $1 \mathrm{~m}$ and the velocity resolution $0.5 \mathrm{~m} / \mathrm{s}$.

The resulting map presents an overview of the flood-prone areas along the Ciliwung River, the most vulnerable locations and the most problematic sections of the river. Based on this map, consequential measures and decisions can be made in view of improving conditions in the area.

Two alternative measures for flood mitigation were briefly discussed in this study. The first, the construction of a diversion canal, diverting a portion of extreme discharge from the Ciliwung River to the Cipanang River and then to the Eastern Floodway, appears insufficient in itself. Nevertheless, in combination with other measures, it could be effective. The second, more 
ambitious measure, increasing channel capacity, appears to be more effective. The biggest obstacles for both measures are land demand and costly, large-scale construction.

\section{Acknowledgements}

Very good working conditions for this study were provided by Institut Teknologi Bandung (ITB) and Czech Technical University (CTU), whose support is gratefully acknowledged. Thanks are owed to experts from both universities concerned for their advice and comments, particularly Aleš Havlík from CTU.

\section{References}

[1] Kusuma, M.S.B., Rahayu, H.P., Farid, M., Adityawan, M.B., Setiawati, T. \& Silasari, R., Studi Pengembangan Peta Indeks Resiko Banjir pada Kelurahan Bukit Duri Jakarta (The Development of Flood Risk Index Map of Bukit Duri Sub-District, Jakarta), Jurnal Teknik Sipil, 17(2), pp. 123-134, 2010.

[2] U.S. Federal Highway Administration, User's Manual for FESWMS Flo2DH, Publication No. FHWA-RD-03-053, 2002.

[3] PT. Dian Cipta Dayarancana, Laporan Akhir Perencanaan dan Detail Desain Penataan Kali Ciliwung dari Pintu Air Manggarai ke Hulu (Planning and Detailed Design of Ciliwung River Regulation from Sluice Gate Manggarai to Hulu, Final Report), 2008.

[4] Yunika, A., Public Health Impact of Urban Flooding: A Case Study of Jakarta, Indonesia, 2005.

[5] Sayaka, B. \& Pasandaran, E., Stage of Development in River Basin Management in Indonesia, The Center of Agricultural Social Economic and Policy Studies, Bogor, 2006.

[6] Rijkswaterstaat and Associates, The Ciliwung-Cisadane Review Plan, BWRMP Twinning Cooperation, IWIRIP-GON, 2004.

[7] Cook, A.C., Comparison of One-Dimensional HEC-RAS with $2 D$ FESWMS Model in Flood Inundation Mapping, 2008.

[8] NEDECO, Master Plan for Drainage and Flood Control of Jakarta, In Main Report, 1973. 